IP Periodica Polytechnica

Mechanical Engineering

62(4), pp. 292-297, 2018

https://doi.org/10.3311/PPme.12194

Creative Commons Attribution (i)

RESEARCH ARTICLE

\section{Investigation of Operating Regimes of Shut-off Hydrovalve with Electrohydraulic-powered Drive}

\author{
Anatoliy Ioffe ${ }^{1}$, Igor Mazur ${ }^{1 *}$
}

Received 12 March 2018; accepted 26 July 2018

\begin{abstract}
The paper suggests the design of the locking truck hydraulic valve with electro-hydraulic drive and braking, which eliminates the disadvantages of the known designs hydraulic valves. A mathematical model for the study of operating modes of the proposed design of hydraulic valve. As a result of research modes of pressure hydraulic valve is installed, it has a highspeed operation. The proposed design of the shut-off tractor hydraulic valve allows you to quickly make adjustment of the time of its operation during operation using the throttle is part of the hydraulic valve.
\end{abstract}

\section{Keywords}

locking valve, electrohydraulic drive, needle throttle, research, speed, movement, reaction time

\footnotetext{
${ }^{1}$ Department Machines and Units of Metallurgical Production, Faculty of Mechanical Engineering, National Metallurgical Academy of Ukraine, 49600 Dnipro, Gagarin Avenue 4, Ukraine

* Corresponding author, e-mail: igor.mazur1974@gmail.com
}

\section{Introduction}

Nowadays the hydraulic systems using technical water or an emulsion are widely used in the metallurgical equipment. Typical representatives of such hydraulic systems are: control of presses for pipes and rolled wheel production; control of the feeder and the feeding device of step-rolled pipe-rolling mill; hydraulic scale force down; thermal hardening of rolled products; working rolls of rolling mills cooling; interstand cooling and to that similar. In these hydraulic systems production control of a working liquid consumption is made by means of the standard, serially produced shutoff valves - valve distributors, shutoff gates as with the manual, and electro mechanical drive as well.

The operating experience of shutoff valves in the listed above hydraulic systems showed that valve distributors, locking gates and locking latches with an electro mechanical drive have one common disadvantage - the big reaction time, about $3-5$ sec. Small speed of these fittings does not allow to create and build high-speed hydraulic systems.

Recently, in these hydraulic systems, widely using of two-linear on-off locking saddle hydrovalves begins. Advantages of these hydrovalves are tightness, high speed and decrease in wear because of saddle performance, small losses of pressure both in hydrovalves, and in connecting channels, a possibility of several functions performance by the hydrovalve, etc. The considered hydrovalves are installed as on pressure head, and drain hydropipelines.

Two-linear on-off locking saddle hydrovalves with the hydraulic and pneumatic drive are known from the review of patent and scientific-technical literature.

The design of the locking saddle hydrovalve with the hydraulic drive of Hemscheidt firm is considered in the present work [1]. This design of the hydrovalve has one essential shortcoming - the reaction time of the hydrovalve depends on properties and characteristics of the spring which is built-in it, as the working cavities areas of the hydrovalve are identical. At the same time hydrovalve reaction time (for opening and closing) will be different. The adjustable throttles provided in a hydrovalve control system allow to stretch reaction time only. Above told does not allow to recustomize the valve quickly. 
The design of the locking saddle hydrovalve with the hydraulic drive of Hauhinco firm is known [2]. In this design of the hydrovalve its opening and closing is carried out by means of connection of a valve hydraulic actuator lower cavity with a source of pressure or with discharge, at the same time the hydraulic actuator upper cavity is constantly connected to pressure source. Reaction time of the hydrovalve depends on time of filling or emptying of the lower cavity of a hydraulic actuator. Filling and emptying of the hydraulic actuator lower cavity happens through nozzles (constant throttles) which are built-in in the hydraulic distributor of control. The main shortcoming of the saddle hydrovalve of Hauhinco firm design is that it cannot be used in the hydraulic systems using technical water of a dirty reverse cycle because of overgrowing and a contamination of nozzles. This shortcoming significantly influences on speed of the valve. Besides, means of braking of the valve before its connecting with a saddle are not provided in a design of the hydrovalve.

The existing designs of locking saddle hydrovalves with the pneumatic drive have the following shortcomings: a limited size range of diameter of conditional pass; need existence of a pneumatic control system. The specified shortcomings of the known designs of locking saddle hydrovalves with a pneumatic actuator developed by Institute of Iron and Steel Metallurgy of National Academy of Sciences of Ukraine [3], and National Metallurgical Academy of Ukraine [4-6] constrain broad application in the hydraulic systems using technical water or an emulsion.

The design of the locking saddle hydrovalve with the electrohydraulic drive and hydraulic braking considered in work [7] is also known. The operating experience of this hydrovalve in the hydraulic systems using technical water or an emulsion showed that its design has a shortcoming. The shortcoming of the considered hydrovalve design consists in a presence of the calibrated opening (a throttle of constant resistance) in the piston of the braking device which in the course of its work overgrows and gets littered. Especially clearly it is shown when the hydrovalve is used in the hydraulic systems using technical water of a dirty reverse cycle. It leads to the fact that the actual reaction time of the hydrovalve is more than the adjusted time of its operation by means of an adjusting throttle. Besides, during the operation of the valve on technical water of a dirty reverse cycle, in the controlling distributor the filtering element 28 gets littered that leads to unsatisfactory operation of the valve in general. At the same time, for cleaning or replacement of the filtering element 28 , it is necessary to dismantle completely the controlling distributor from the hydrovalve that leads to increase in maintenance time of the valve.

\section{Purpose}

Author offered the design of the locking saddle hydrovalve with the electrohydraulic drive and hydraulic braking presented in Fig.1, differing from the described in work [7] by feature that in the offered design there is no through opening in the piston of the hydraulic braking device being a throttle of inertial resistance. Besides, it is offered to use in the pipeline of a working liquid supply to the controlling distributor the filter of rough cleaning 29 . It allows to increase reliability of work of normally open, ceramic $3 / 2$ hydraulic valves of Hauhinco firm (Fig. 1(b)) on technical water of a dirty reverse cycle.

At the same time, the principle of a new design of the hydrovalve operation practically does not differ from the known design of the hydrovalve considered in article [7]. The main difference in operation is that the flow out or filling of the hydrovalve braking device cavity the worker liquid happens only through a needle throttle.

\section{Technique of researches}

Operation of controlling locking saddle hydrovalves exerts a great influence on transition processes in hydraulic systems of the metallurgical equipment. At incorrectly chosen design data of hydrovalves in hydraulic system there can be hydroblows. Therefore, at dynamic calculations of hydraulic systems equipment the last need to be considered together with dynamic model of controlling valves.

Let's consider the standard calculating scheme (Fig. 2) of a design of the locking saddle hydrovalve with the electrohydraulic drive and hydraulic braking.

The equation of the movement of the considered hydrovalve mobile parts taking into account forces viscous and Coulomb friction is as follow $[8,9]$ :

$$
\begin{aligned}
& m_{v a l} \frac{d^{2} y}{d t^{2}}-G_{v a l}-p_{\text {h.a. }} f_{\text {h.a. }}+p_{\text {b.d. }} f_{b . d .}^{p} \\
& +C\left(p_{\text {val }}^{b}-p_{\text {val }}^{o}\right) f_{v a l}+h\left(\frac{d y}{d t}\right) \\
& +T_{f r} \operatorname{sign}\left(\frac{d y}{d t}\right)+p_{\text {val }}^{b}\left(f_{\text {b.d. }}^{r}-f_{v a l}\right)=0
\end{aligned}
$$

where:

$m_{v a l}-$ mass of the valve $(\mathrm{kg})$,

$G_{v a l}$ - weight of the valve mobile parts (N),

$h$ - coefficient of viscous friction on valve plunger,

$C$ - coefficient of hydrodynamic impact of a liquid flow on valve plunger,

$T_{f r}$ - total friction force in sealings of the valve $(\mathrm{N})$,

$v$ - speed of the valve plunger $(\mathrm{m} / \mathrm{s})$,

$y$ - stroke of the valve plunger (mm),

$f_{\text {h.a. }}$ - area of the valve hydraulic actuator piston $\left(\mathrm{m}^{2}\right)$,

$f_{v a l}$ - area of the valve plunger $\left(\mathrm{m}^{2}\right)$,

$f_{b . d \text {. }}^{p}$ - area of the valve hydraulic braking device piston cavity $\left(\mathrm{m}^{2}\right)$,

$f_{b . d .}^{r}$ - area of the valve hydraulic braking device rod cavity $\left(\mathrm{m}^{2}\right)$, $p_{\text {h.a. }}$ - pressure of working liquid in the valve hydraulic actuator piston cavity $(\mathrm{Pa})$,

$p_{\text {val }}^{b}$ - pressure of working liquid below a valve plunger $(\mathrm{Pa})$,

$p_{\text {val }}^{o}$ - pressure of working liquid over a valve plunger $(\mathrm{Pa})$, 


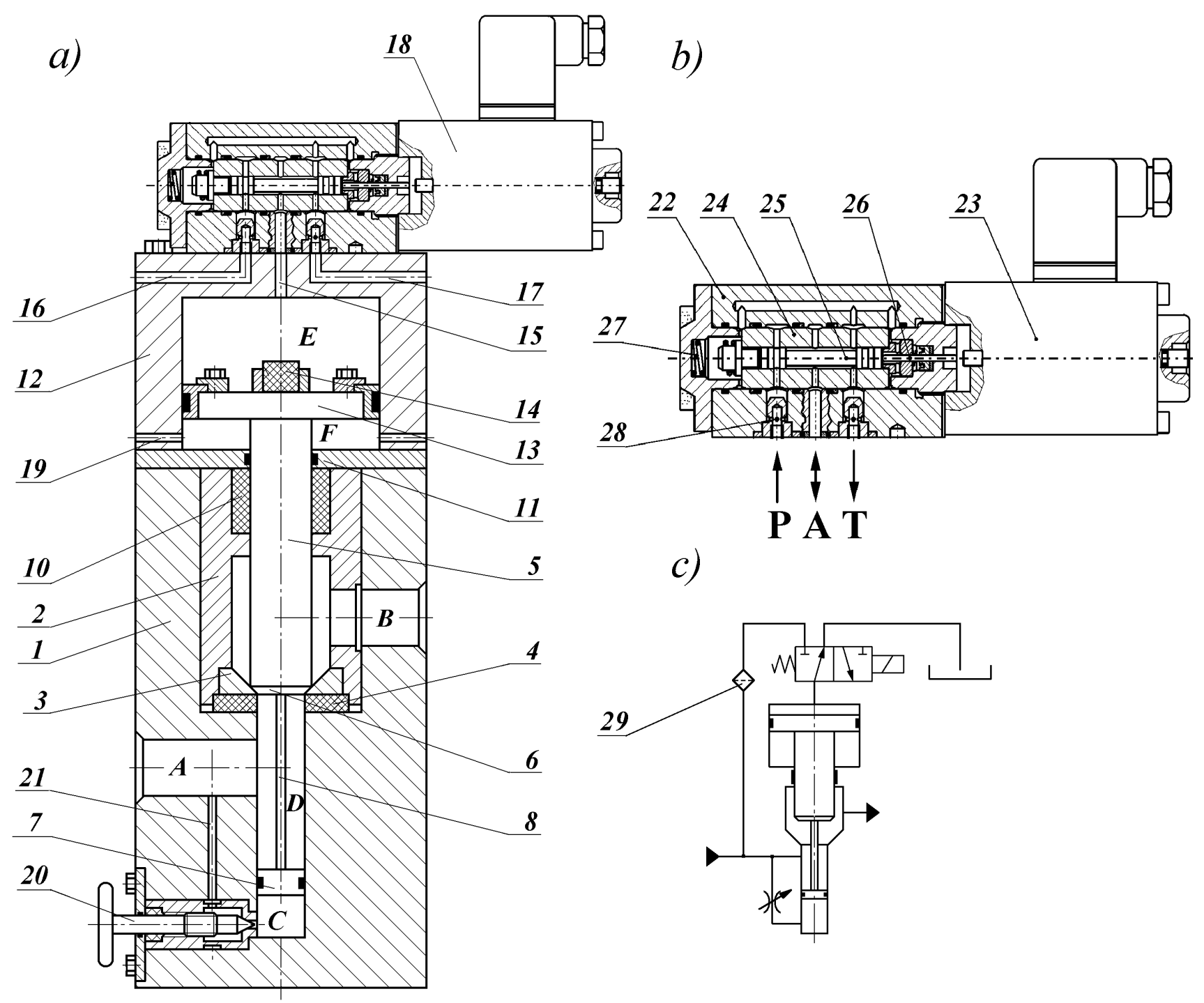

Fig. 1 The locking saddle hydrovalve with the electrohydraulic drive and the hydraulic braking device (caption texts are given in work [7])

$p_{b . d .}$ - pressure of working liquid in the valve the hydraulic braking device $(\mathrm{Pa})$.

Pressure of working liquid in the valve hydraulic actuator piston cavity can be determined from expression: at hydrovalve closing:

$$
\frac{d p_{\text {h.a. }}}{d t}=\frac{E_{l}}{\left(l_{\text {h.a. }}^{0}+y\right) f_{\text {h.a. }}}\left(q_{\text {dis }}-f_{\text {h.a. }} \frac{d y}{d t}\right)
$$

at hydrovalve opening:

$$
\frac{d p_{\text {h.a. }}}{d t}=\frac{E_{l}}{\left(l_{\text {h.a. }}^{0}+h_{\text {val }}-y\right) f_{\text {h.a. }}}\left(f_{\text {h.a. }} \frac{d y}{d t}-q_{\text {dis }}\right)
$$

where:

$E_{l}$ - the elastic modulus of working liquid (Pa),

$h_{v a l}$ - working stroke of a hydrovalve plunger (m),

$l_{\text {h.a. }}^{0}-$ length of initial volume of the valve hydraulic actuator working cavity (m),

$q_{d i s}-$ a consumption of working liquid via the controlling distributor $\left(\mathrm{m}^{3} / \mathrm{s}\right)$.
The consumption of working liquid by the controlling distributor, when filling or emptying a hydraulic actuator piston cavity, is defined from expression:

at hydrovalve closing:

$$
q_{d i s}=\mu_{d i s} f_{d i s}^{c}(t) \sqrt{\frac{2}{\rho}\left|p_{p r}-p_{\text {h.a. }}\right|} \operatorname{sign}\left(p_{p r}-p_{\text {h.a. }}\right)
$$

at hydrovalve opening:

$$
q_{\text {dis }}=\mu_{\text {dis }} f_{\text {dis }}^{o}(t) \sqrt{\frac{2}{\rho}\left|p_{\text {h.a. }}-p_{d r}\right|} \operatorname{sign}\left(p_{\text {h.a. }}-p_{d r}\right)
$$

where:

$\mu_{d i s}$ - coefficient of liquid consumption via the controlling distributor,

$f_{\text {dis }}^{c}(t)$ - change of the area of the section passage when closing the controlling distributor $\left(\mathrm{m}^{2}\right)$,

$f_{d i s}^{o}(t)$ - change of the area of the section passage when opening the controlling distributor $\left(\mathrm{m}^{2}\right)$,

$p_{p r}$ - pressure of working liquid in pressure head hydropipelines of control $(\mathrm{Pa})$, 


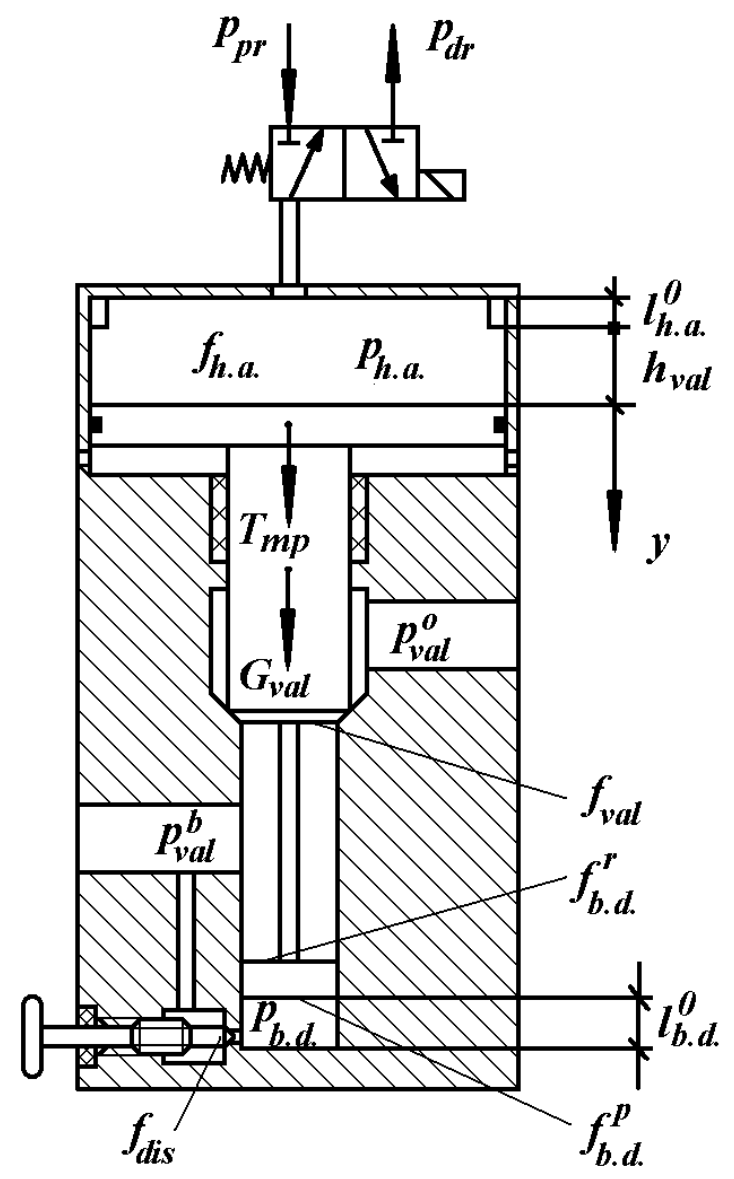

Fig. 2 The calculating scheme of the locking saddle hydrovalve with the electrohydraulic drive

$p_{d r}-$ pressure of working liquid in drain hydropipelines of control $(\mathrm{Pa})$.

For adequate modeling of the dynamic phenomena in the valve hydraulic actuator it is necessary to consider not instantaneousness operation of the controlling distributor. Researches of operation nature of zolotnik type distributing devices [10] in the conditions of a volumetric hydraulic actuator showed that the section through passage changes practically under the linear law: at closing:

$$
f_{\text {dis }}^{c}(t)=f_{\text {dis }}^{\max }\left(1-\frac{1}{t_{c}}\right)
$$

at opening:

$$
f_{\text {dis }}^{o}(t)=f_{\text {dis }}^{\max } \frac{1}{t_{o}}
$$

where:

$f_{\text {dis }}^{\max }(t)$ - the maximum area of the section through passage of the controlling distributor $\left(\mathrm{m}^{2}\right)$,

$t_{c}$ - closing time of the controlling distributor operating part ( $\mathrm{sec}$ ), $t_{o}$ - opening time of the controlling distributor operating part ( $\mathrm{sec}$ ).

Pressure of working liquid in the valve braking device piston cavity can be determined from expression: at hydrovalve closing:

$$
\frac{d p_{b . d .}}{d t}=\frac{E_{l}}{\left(l_{b . d .}^{0}+y\right) f_{b . d .}^{p}}\left(q_{t h r}-f_{b . d .}^{p} \frac{d y}{d t}\right)
$$

at hydrovalve opening:

$$
\frac{d p_{b . d .}}{d t}=\frac{E_{l}}{\left(l_{b . d .}^{0}+h_{v a l}-y\right) f_{b . d .}^{p}}\left(f_{b . d .}^{p} \frac{d y}{d t}-q_{t h r}\right)
$$

where:

$l_{b . d}^{0}$. - length of initial volume of the hydraulic braking device working cavity $(\mathrm{m})$,

$q_{\text {thr }}$ - consumption of working liquid through a needle throttle $\left(\mathrm{m}^{3} / \mathrm{s}\right)$.

The consumption of working liquid through a needle throttle at filling or emptying of the hydraulic braking device working cavity is defined by from expression:

$$
q_{d i s}=\mu_{t h r} f_{t h r} \sqrt{\frac{2}{\rho}\left|p_{v a l}^{b}-p_{b . d .}\right|} \operatorname{sign}\left(p_{v a l}^{b}-p_{b . d .}\right)
$$

where:

$\mu_{t h r}$ - consumption coefficient through a needle throttle,

$f_{t h r}$ - area of the passage section through of a needle throttle $\left(\mathrm{m}^{2}\right)$.

As an example, we investigate the opening and closing modes of the locking saddle hydrovalve with electrohydraulic controlling and hydraulic braking installed on the pressure head pipeline at the following parameters: $m_{v a l}=5 \mathrm{~kg} ; G_{v a l}=50 \mathrm{~N}$; $p_{\text {val }}^{b}=p_{p r}=30 \cdot 10^{6} \mathrm{~Pa} ; p_{\text {val }}^{o}=p_{d r}=1.0 \cdot 10^{6} \mathrm{~Pa} ; f_{\text {h.a. }}=0.00312 \mathrm{~m}^{2}$; $f_{b . d .}^{p}=0.0023 \mathrm{~m}^{2} ; f_{b . d .}^{r}=f_{v a l}=0.002123 \mathrm{~m}^{2} ; h_{v a l}=0.013 \mathrm{~m}$; $T_{f r}=100 \mathrm{~N} ; E_{l}=2 \cdot 10^{9} \mathrm{~Pa}[11] ; h=2.8 \cdot 10^{-4} ; C=0.001 ;$ $\mu_{\text {dis }}=0.4 ; \mu_{\text {thr }}=0.2 ; \rho=1000 \mathrm{~kg} / \mathrm{m}^{3} ; f_{\text {dis }}^{\max }=0.000201 \mathrm{~m}^{2}$; $l_{\text {b.d. }}^{0}=l_{\text {h.a. }}^{0}=0.05 \mathrm{~m}$.

In this case for a research of the offered design of the hydrovalve operating modes the section through passage area size of a needle throttle was chosen as the varied parameter $f_{t h}$. Results of a research of operating modes of the hydrovalve are presented in the form of diagrams of speed $v_{v a l}$ and stroke $y_{v a l}$ of a plunger of the pressure head hydrovalve at closing (Fig. 3) and opening (Fig. 4) depending on size $f_{t h}$.

\section{Conclusions}

On the basis of operating modes of the pressure head saddle hydrovalve with electrohydraulic controlling analysis at the closing and opening received for different sizes $f_{\text {thr }}$ it is possible to make the conclusion that the nature of change of plunger movement speed $v_{v a l}$ and consequently, the plunger stroke $y_{v a l}$ for the set distance are not identical and significantly differ. At the same time, at the section through passage area $f_{t h r}$ increase, the speed of the hydrovalve plunger motion $v_{v a l}$ increases that as a result affects the hydrovalve speed. It indicates the need to set the throttle through passage section area $f_{\text {thr }}$, proceeding from the necessary reaction time. Besides, it is 
a)
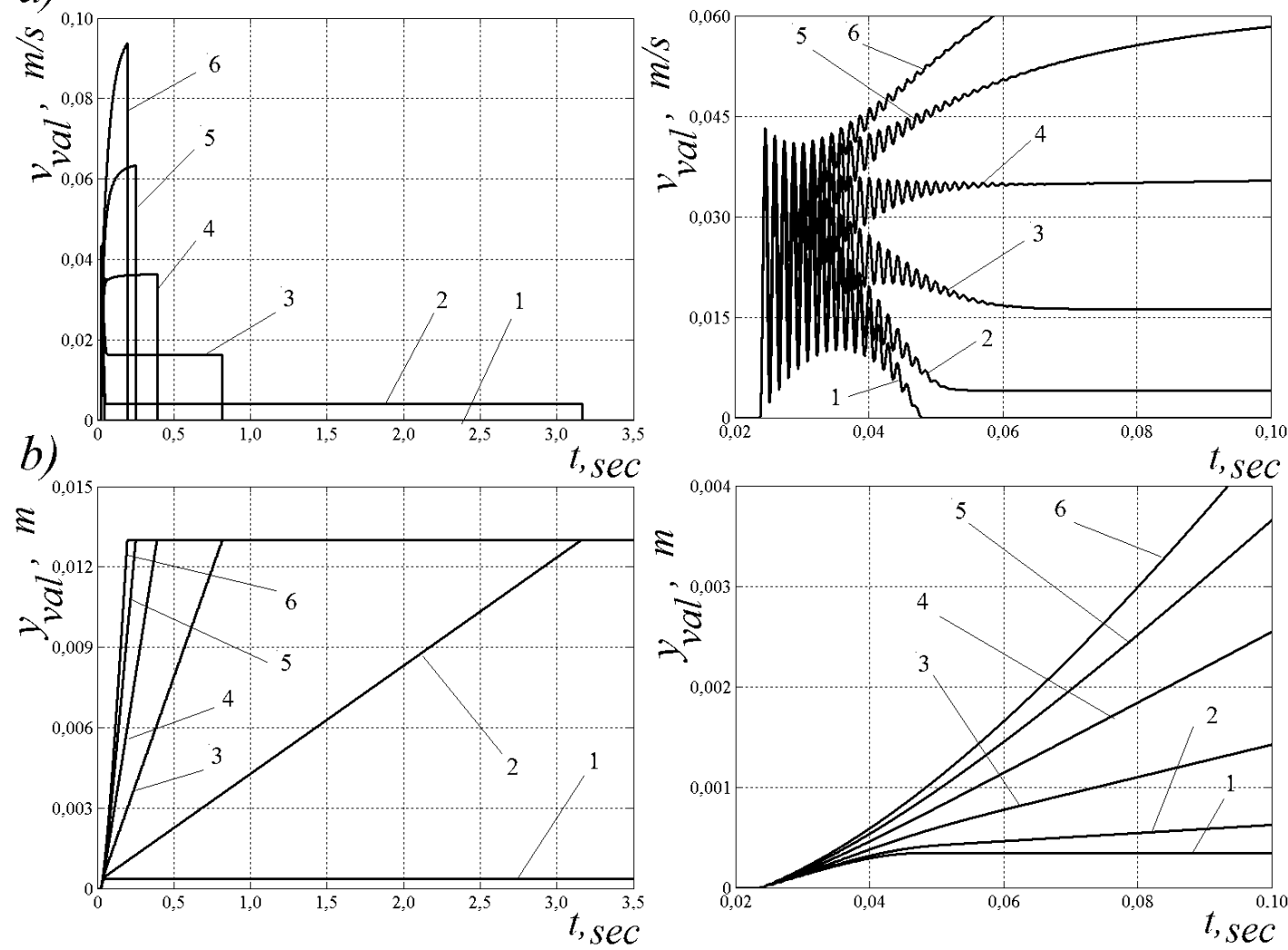

Fig. 3 Operating modes of the locking saddle hydrovalve with electrohydraulic management when closing, depending on the area of the section through passage of a throttle $f_{\text {thr }}:$ a) the locking hydrovalve plunger movement speed; b) the locking hydrovalve plunger stroke: 1 - at $f_{\text {thr }}=0 ; 2$ - at $f_{\text {thr }}=3.14 \cdot 10^{-6} \mathrm{~m}^{2} ; 3$ - at $f_{t h r}=1.256 \cdot 10^{-5} \mathrm{~m}^{2} ; 4-$ at $f_{\text {thr }}=2.826 \cdot 10^{-5} \mathrm{~m}^{2} ; 5-$ at $f_{\text {thr }}=5.024 \cdot 10^{-5} \mathrm{~m}^{2} ; 6-$ at $f_{\text {thr }}=7.85 \cdot 10^{-5} \mathrm{~m}^{2}$.
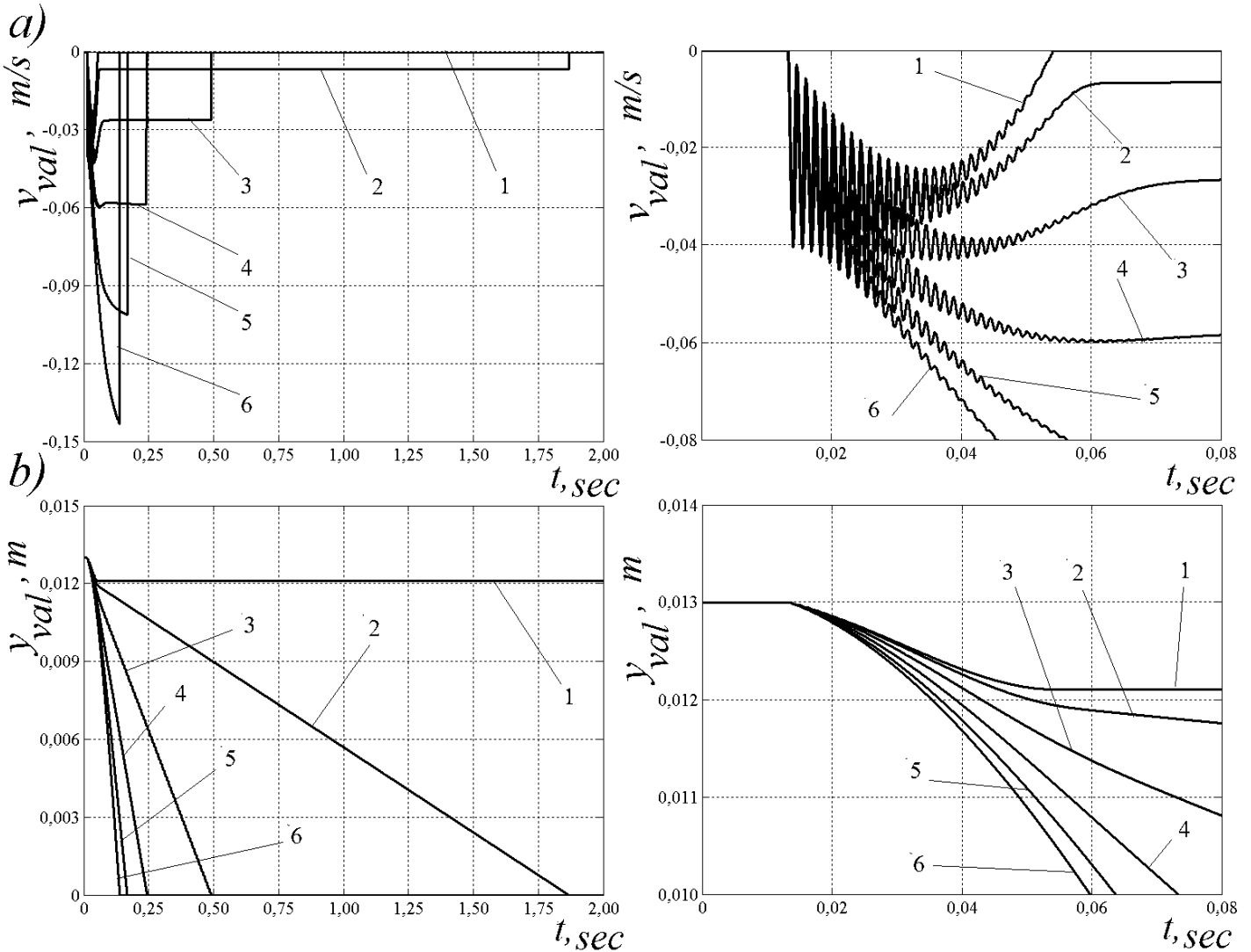

Fig. 4 Operating modes of the locking saddle hydrovalve with electrohydraulic controlling at opening, depending on the through passage section area of a throttle $f_{t h r}$ : a) the locking hydrovalve plunger movement speed; b) the locking hydrovalve plunger stroke: 1 - at $f_{\text {thr }}=0 ; 2-$ at $f_{\text {thr }}=3.14 \cdot 10^{-6} \mathrm{~m}^{2} ; 3-$ at $f_{\text {thr }}=1.256 \cdot 10^{-5} \mathrm{~m}^{2} ; 4-$ at $f_{\text {thr }}=2.826 \cdot 10^{-5} \mathrm{~m}^{2} ; 5-$ at $f_{\text {thr }}=5.024 \cdot 10^{-5} \mathrm{~m}^{2} ; 6-$ at $f_{\text {thr }}=7.85 \cdot 10^{-5} \mathrm{~m}^{2}$. 
necessary to pay attention that at completely closed throttle, the hydrovalve when closing and opening has insignificant movement. It can be explained by the fact that the valve hydraulic actuator piston area is more than the braking device piston area.

\section{References}

[1] Hovorka, R. "Patents DE 3741521 C1 Germany, F15B13/042. 2/2-Wege-Sitzventil seat valve." (2/2-way seat valve.) Hermann Hemscheidt Maschinenfabrik GmbH \& Co. 1989.

[2] Hauhinco. "2/2 Wegeventil C1." (2/2-way valve.) [Online]. Available from: http://www.hauhinco.de/fileadmin/documents/downloadcen-ter/ valves/DE/Hauhinco-2_2-Wegesitzventil_C1-DN16_125-PN320_X-Ygesteuert.pdf [Accessed: 29th December 2017] (in German)

[3] Ioffe, A. M., Kukushkin, O. N., Levchuk, E. K., Naumchuk, F. A., Novitskiy, V. N., Sergieni, V. A., Smal'ko, V. N., Tomashev, L. A. "Pravila tekhnicheskoy ekspluatatsii gidroprivodov na predpriyatiyakh chernoy metallurgii." (The technical operation of hydraulic actuators on the iron and steel enterprises.) Gektor, St. Petersburg, Russia. 1992. (in Russian)

[4] Ioffe, A. M., Mazur, I. A. "Konstruktsiya i issledovanie rezhimov raboty zapornogo sedel'nogo gidroklapana s pnevmaticheskim privodom." (Design and research of modes of operation of the shut-off saddle hydraulic valve with pneumatic drive.) Metallurgicheskaya i Gornorudnaya Promyshlennost. 5, pp. 117-121. 2010. (in Russian)

[5] Ioffe, A. M., Mazur, I. A. "Issledovanie rezhimov raboty zapornogo sedel'nogo gidroklapana s pnevmaticheskim privodom." (Study modes of locking saddle hydraulic valve with pneumatic drive.) Metallurgicheskaya i Gornorudnaya Promyshlennost. 3, pp. 95-99. 2015. (in Russian)
[6] Ioffe, A., Mazur, I. "Investigation of operating regimes of locking seat hydrovalve with air-powered drive." Metallurgical and Mining Industry. 1, pp. 55-61. 2015.

[7] Ioffe, A. M., Mazur, I. A. "Konstruktsiya i issledovanie rezhimov raboty zapornogo sedel'nogo gidroklapana s elektrogidravlicheskim privodom." (Design and research of modes of operation of the shut-off saddle hydraulic valve with electrohydraulic drive.) Metallurgicheskaya $i$ Gornorudnaya Promyshlennost. 3, pp. 95-100. 2012. (in Russian)

[8] Kozhevnikov, S. N., Peshat, V. F. "Gidravlicheskiy i pnevmaticheskiy privody metallurgicheskikh mashin." (Hydraulic and pneumatic actuators metallurgical machines.) Mashinostroenie, Moscow, Russia. 1973. (in Russian)

[9] Prazdnikov, A. V. "Gidroprivod v metallurgii." (Hydraulic metallurgy.) Mashinostroenie, Moscow, Russia. 1973. (in Russian)

[10] Ioffe, A. M., Kukushkin, O. N., Lopatenko, K. P., Mikhaylovskiy, N. V. "Opredelenie dinamicheskikh nagruzok $v$ gidrosistemakh metallurgicheskikh agregatov pri pomoshchi matematicheskogo modelirovaniya."(Determination of dynamic loads in the hydraulic systems of metallurgical units with the help of mathematical modeling.) Mashinostroenie, Moscow, Russia. 1986. (in Russian)

[11] Zhukovskiy, N. E. "O gidravlicheskom udare v vodoprovodnykh trubakh." (About water hammer in water pipes.) Gostekhizdat, Moscow and Leningrad, Russia. 1949. (in Russian) 